\title{
Kimberlites from the Archangelsk region - A rock type transitional between kimberlites, melnoites and lamproites.
}

\author{
Mahotkin, I.L.', Skinner, E.M.W. ${ }^{2}$ \\ 1. De Beers Centenary (Russia), Ul. Tverskaya 22a, Moscow, 103050, Russia \\ 2. Geology Department, Rhodes University, Grahamstown, 6140, South Africa
}

Group I and Group II kimberlites differ from each other with respect to mineral assemblages, mineral chemistries and whole-rock isotope and major element geochemistry (Smith, C.B., 1983, Skinner, E.M.W., 1989 and Mitchell, R.H. 1995). Highly- and poorly-diamondiferous kimberlites from the Archangelsk region, Russia exhibit characteristics that are different from both groups of kimberlites. Furthermore the Archangelsk kimberlites are, spatially and petrologically, closely associated with melilititic and basaltic rock types also occurring in this region.

Most of the hypabyssal-facies rocks of the low-Ti, Pionerskaya pipe as well as high-Ti pipes, including Shocha and Anomaly- 441 are phlogopite-(Ti-clinohumite-monticellite-?), macrocrystic kimberlites (fig. 1, a). As such they are petrographically intermediate between Group I and II types. Hydrogarnet (andradite-schorlomite with $\mathrm{TiO}_{2}$ up to 20 wt. \%) is a common accessory mineral in the hypabyssal-facies rocks of the Pionerskaya pipe. This hydrogarnet forms during late magmatic and metasomatic stages of crystallisation. Some specimens from the Pionerskaya pipe are transitional hypabyssal-/ diatreme-facies, serpentinediopside-phlogopite, segregationary kimberlites (Clement and Skinner, 1985), similar in petrographic character to some of the kimberlites of the Group II, Finsch kimberlite in South Africa. Most of the diatreme-facies kimberlites of the Archangelsk region contain relatively abundant (up to 10 vol. \%) pseudomorphs after melilite in juvenile lapilli (fig. 1, b). Possible altered Ti-clinohumite (with $\mathrm{Cl}$ up to $1 \mathrm{wt}$. \%) may also be recognised in the groundmass of some phlogopite-enriched varieties from Karpinskiy and Pionerskaya pipes (fig. 1). Most of the high Ti-series rocks from the Zvezdochka, Anomaly-687 and Anomaly-697 exhibit melnoitic affinities or are melnoites. The groundmass of the Anomaly-697 melnoite consists of Ti-hydroandradite, phlogopite, perovskite, altered kirchsteinite (Fe-monticellite), merwinite and probable clinohumite. A fine-grained mixture of Ti-magnetite, $\mathrm{MnO}$-rich (up to $23 \mathrm{wt}$ \%) ilmenite and rutile occurs in the groundmass of rocks from the Shocha sills. These intergrowths of Ti-rich minerals and serpentite could originate as a result of the breakdown of Ti-clinohumite in the late magmatic stages of crystallisation.

The groundmass micas in monticellite-bearing kimberlites have low $\mathrm{Al}_{2} \mathrm{O}_{3}$ contents (fig. 2) that are typical of Group II kimberlites and of some ultramafic lamprophyres and alnoites (Mitchell, 1995). Mica microphenocrysts in melilite- and monticellite-bearing, pelletal, tuffisitic kimberlites (re. Clement and Skinner, 1985) have high $\mathrm{Al}_{2} \mathrm{O}_{3}$ contents similar to those of Group I kimberlites and alnoites. Compositional trends of micas, in the both low- and high-Ti kimberlites are intermediate in character compared with micas in Group I, Group II kimberlites and ultramafic lamprohyres (alnoites) (fig. 2).

The low- $\mathrm{Ti}$ series kimberlites have relatively high $\mathrm{K}_{2} \mathrm{O}$ and $\mathrm{SiO}_{2}$ contents and their compositions fit into the Fo- $\mathrm{Ph}$ - Di-Ak subsystem of the normative tetrahedron for the system Ks-La-Fo-Qz (Yoder, 1986) (fig. 1, Mahotkin, this Volume). The high-Ti series rocks have low $\mathrm{SiO}_{2}$ and $\mathrm{CaO}$ contents and their compositions mostly fit into the Fo-Sa-Di-En subsystems. 
Sr-Nd isotope compositions for all low-Ti kimberlites and some high-Ti kimberlites are intermediate between those of Group I and Group II kimberlites (fig. 3) indicating a separate mantle source. South African examples of isotopically transitional kimberlites include Frank Smith (Smith, 1983), and several kimberlites in the region to the south of Prieska, South Africa (Skinner et al., 1994). The Frank Smith kimberlite and others in close proximity to this pipe are petrographically similar to the Archangelsk bodies but the transitional kimberlites in the Prieska region are distinctly different.

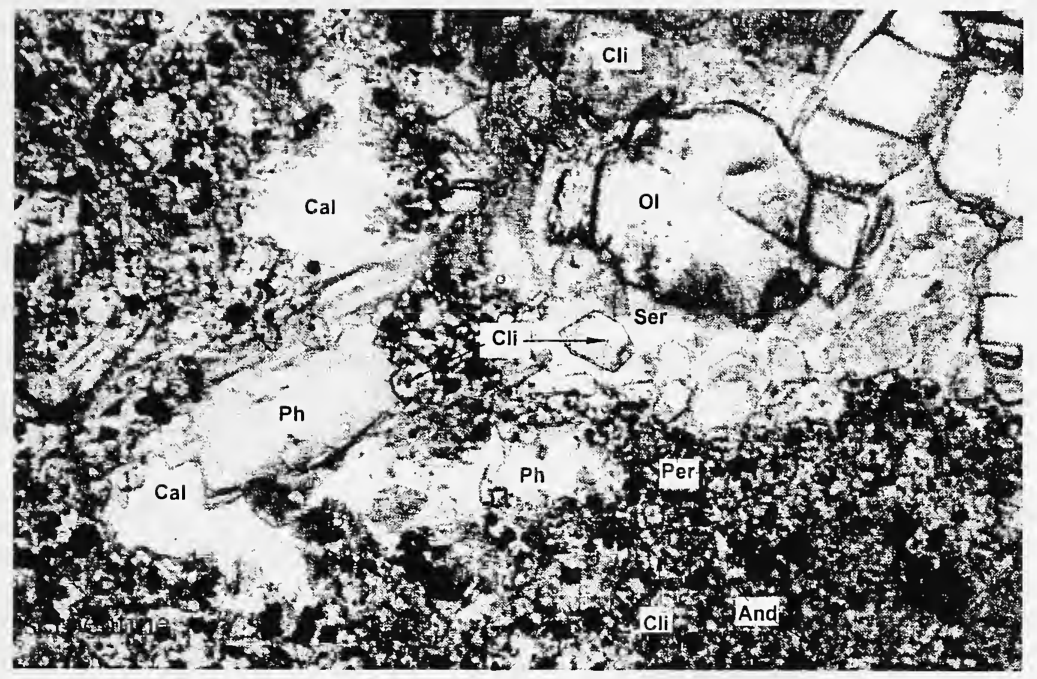

Fig. 1 a. Hypabyssal macrocrystic phlogopite-clinohumite (monticellite?) kimberlite from Pionerskaya pipe, sample 1490/1048, magnification $90^{x}$, Cli-Ti-clinohumite, $\mathrm{Ph}$ - phlogopite, Ol - olivine (fresh), And - Ti-andradite Cal - calcite,

Per - perovskite, Ser-

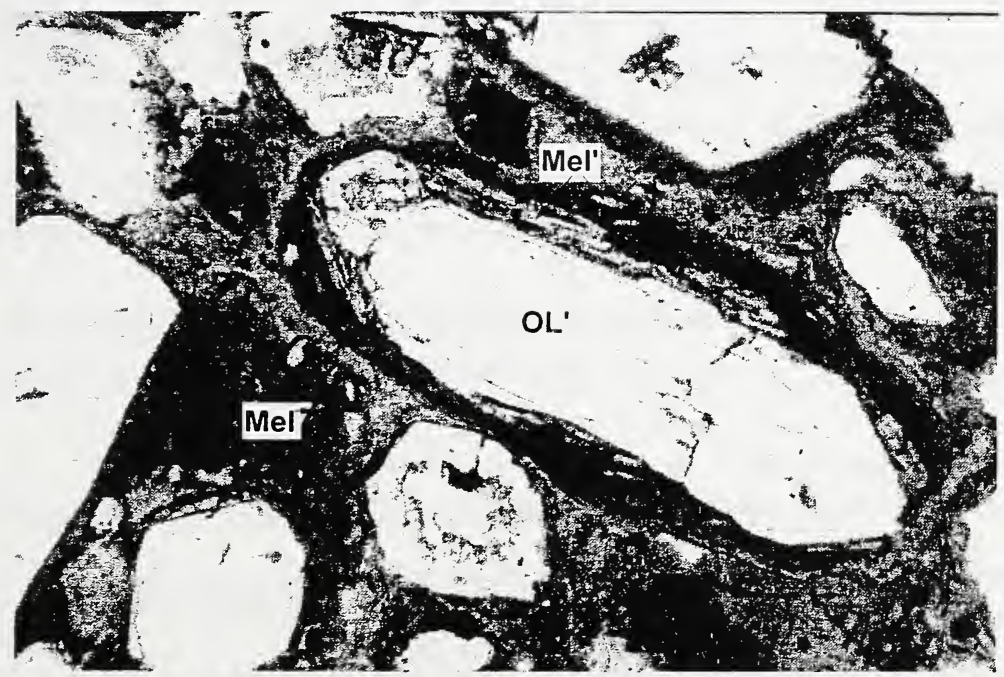

Fig. 1 b. Pelletaltuffisitic melilitephlogopite kimberlite from Karpinskiy-II pipe, sample $81 / 280$, magnification $45 \mathrm{x}$, Nik. II, Mel'- altered melilite in juvenile lapillus and autoliths. Segregationary texture of autoliths. 

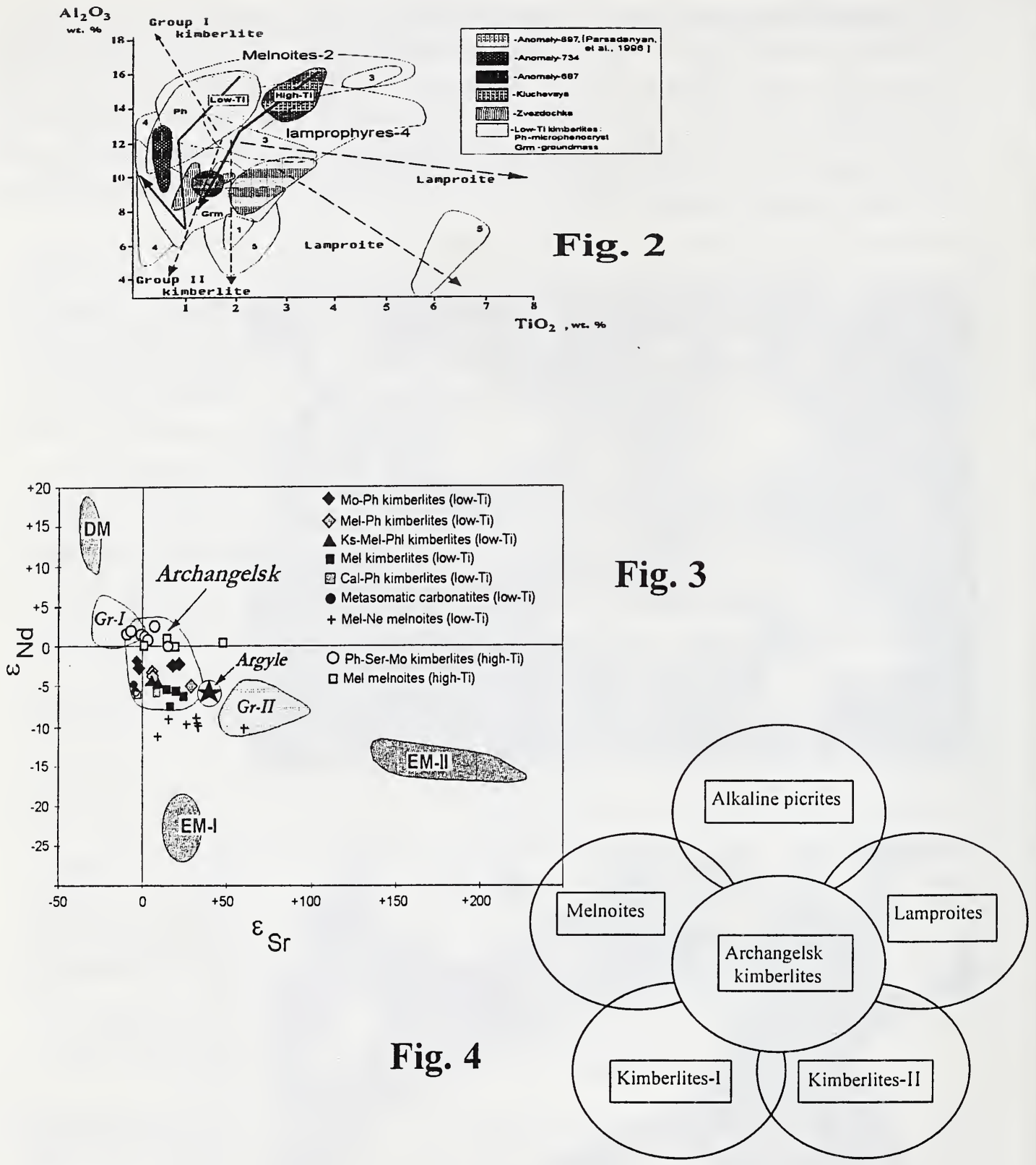

\section{References}

Clement, C.R. and Skinner, E.M.W., 1985, A textural-genetic classification of kimberlites: Trans. Geol. S. Afr., v. 88, pp.403-409.

Mahotkin, I.L.,(This Conference), Petrology of Group 2 kimberlite-olivine lamproite series from the Kostomuksha area, Karelia, NW Russia.

Mitchell, R. H., 1995, Kimberlites, Orangeites and related Rocks, Plenum Press, NY, pp.

Smith, C. B., 1983, Pb, $\mathrm{Sr}$, and $\mathrm{Nd}$ isotopic evidence for sources of African Cretaceous kimberlite: Nature, v. 304, pp. 51-54.

Skinner, E. M. W., 1989, Contrasting Group ! and Group II kimberlite petrology: towards a genetic model for kimberlites: In Ross et al., v.1, p. 528-544.

Skinner, E.M.W., Vilijoen, K.S., Klark, T.C. and Smith, C.B., 1994, The petrography, tectonic setting and emplacement ages of kimberlites in the south western border region of Kaapvaal craton, Prieska area, RSA. Kimberlites, Related rocks and Mantle Xenoliths, v.1, Proc. $5^{\text {th }}$ Int. Kimb. Conf, p. 80-97. 